GRASAS Y ACEITES, 62 (1), ENERO-MARZO, 55-61, 2011, ISSN: 0017-3495

DOI: $10.3989 /$ gya.033810

\title{
Chemical composition, antioxidant and antimicrobial activity of the essential oil and methanol extract of the Egyptian lemongrass Cymbopogon proximus Stapf
}

\author{
By Samy A. Selim \\ Botany Department (Microbiology Section), Faculty of Sciences, Suez Canal University, \\ Ismailia, P.O.41522, Egypt. \\ ( ${ }^{*}$ Corresponding author: sadomm@yahoo.com)
}

\begin{abstract}
RESUMEN
Composición química, actividad antioxidante y antimicrobiana del aceite esencial y extractos de metanol de limoncillo egipcio Cymbopogon proximus Stapf.

El presente estudio fue llevado a cabo para evaluar las propiedades antioxidantes y antimicrobianas in vitro del aceite esencial (Eo) y extractos de metanol de una genuina y endémica planta egipcia, Cymbopogon proximus Stapf. La composición química de un hidrodestilado Eo de $C$. proximus fue analizado por GC y GC/MS. Un total de 19 constituyentes representando el $95.47 \%$ del aceite fueron identificados; piperitona $(72.44 \%)$, elemol $(9.43 \%)$, $\alpha$-eudesmol $(4.34 \%)$, limoneno (2.45\%) and $\beta$-eudesmol (1.26\%) fueron los principales componente, que comprenden el $88.92 \%$ del aceite. Los resultados de los ensayos antimicrobianos mostraron que el Eo de $C$. proximus inhibió fuertemente el crecimiento de las bacterias ensayadas, aunque no el de las especies de levaduras, mientras que el extracto de metanol tuvo una moderada actividad antibacteriana, pero ninguna actividad anti-candida. Bacillus cereus and Salmonella choleraesuis fueron las más susceptibles con Eo. El tiempo de exposición con Eo para una completa inhibición de la viabilidad celular de $B$. cereus y $S$. choleraesuis fue de $10 \mathrm{~min}$ con un $5 \%$ y 10 min con $1 \%$, respectivamente. El potencial antioxidante de las muestra fue evaluado usando el método de inhibición del radical libre 2,2-difenil-1- picrilhidrazyil (DPPH). Los extractos de metanol fueron capaces de reducir el radical libre estable DP$\mathrm{PH}$ con un $\mathrm{IC}_{50}$ de $48.66 \pm 3.1 \mu \mathrm{g} / \mathrm{ml}$. Los resultados presentados aquí pueden sugerir que el Eo y los extractos de C. proximus poseen propiedades antioxidantes y antimicrobianas, y además, ellos pueden ser usados como ingrediente en la conservación de alimentos y/o en la industria farmacéutica.
\end{abstract}

PALABRAS CLAVE: Antimicrobiano - Antioxidante Composición química - Cymbopogon Proximus - Eo.

\section{SUMMARY}

Chemical composition, antioxidant and antimicrobial activity of the essential oil and methanol extract of the Egyptian lemongrass Cymbopogon proximus Stapf.

The present study was conducted to evaluate the in vitro antimicrobial and antioxidant properties of the essential oil (Eo) and methanol extract from a unique, Egyptian endemic plant, Cymbopogon proximus STAPF. The chemical composition of a hydrodistilled Eo of $C$. proximus was analyzed by a GC and GC/MS system. A total of 19 constituents representing $95.47 \%$ of the oil were identified: piperitone $(72.44 \%)$, elemol $(9.43 \%)$, $\alpha$ - eudesmol (4.34\%), limonene (2.45\%) and $\beta$ - eudesmol
$(1.26 \%)$ were the main components comprising $88.92 \%$ of the oil. The antimicrobial test results showed that the Eo of $C$. proximus strongly inhibited the growth of the test bacteria studied, except for yeast species while the methanol extract had moderate antibacterial, but no anti-candida activity. Bacillus cereus and Salmonella choleraesuis were proven to be the most susceptible against Eo. The exposure time of Eo for complete inhibition of cell viability of $B$. cereus and $S$. choleraesuis were found to be $5 \%$ at $10 \mathrm{~min}$ and $1 \%$ at 10 $\mathrm{min}$, respectively. The antioxidative potential of the samples was evaluated using methods of inhibition of the free radical 2,2-diphenyl-1- picrylhydrazyl (DPPH) system. The methanol extract was able to reduce the stable free radical DPPH with an $\mathrm{IC}_{50}$ of $48.66 \pm 3.1 \mu \mathrm{g} / \mathrm{ml}$. The results presented here may suggest that the Eo and extracts of $C$. proximus possess antimicrobial and antioxidant properties, and therefore, can be used as natural preservative ingredients in food and/or pharmaceuticals.

KEY-WORDS: Antimicrobial - Antioxidant - Chemical composition - Cymbopogon Proximus - Eo.

\section{INTRODUCTION}

Knowledge about the medicinal plants of the Ancient Egyptians came to us through the offerings of the dead found in tombs, the earliest designs and inscriptions on the walls of temples, and the records available in papyri such as the Ebers Papyrus (1500 BC). These show that the Ancient Egyptians were acquainted with a great number of medicinal plants and their products. There are also others which were known to the Egyptians in the days of the Ancient Greeks and Romans. In addition, some medicinal plants were also brought by the Arabs (Sayed, 1980).

The genus Cymbopogon, a member of the family Gramineae, is widely distributed in tropical and subtropical regions. Several species yield essential oils used in soap, perfumery and other related industries. C. citratus Stapf and C. flexuosus Stapf commonly known as lemongrass are native to India and Sri Lanka. Several studies reported antimicrobial activities in lemongrass (C. citratus) oil (Onawunmi, 1980, Hammer et al., 1999; Saikia et al., 2001; Appendini and Hotchkiss, 2002; Daferera et al., 2003; Pereira et al., 2004; Leimanna et al., 2009). 
C. proximus Stapf is a weed known as Halfa bar that grows in the Egyptian desert. It is highly reputed in Egyptian folk medicine as an effective renal antispasmodic and diuretic agent (Taeckholm, 1974; Boulos, 1984; El-Askary et al., 2003). C. proximus is an ascending densely tufted perennial grass, common in the hills and rocky grounds of Elba and the sandy coast of the Red Sea on the southern boundaries of Egypt. The entire dried herb has been used for centuries by the Bisharin and Ababda tribes of the Aswan Province in the form of a decoction to produce diuresis, to relieve colicky pains, to help the removal of small stones from the urinary tracts, and as an antipyretic in fevers. A bicyclic sesquiterpene diol, proximadiol with unique antispasmodic properties has been isolated from C. proximus leaves (Radwan, 1975). Proximol possesses unique antispasmodic properties as it produces relaxation of the smooth muscle fibers without abolishing the propulsive movement of the tissue (El-Askary et al., 2003). The success of proximol in the propulsion of renal and uteric calculi is attributed to this pharmacological characteristic, by which uteric dilation occurs without paralysis and the propulsive waves are preserved. It is quite a safe drug and prolonged use in the recommended therapeutic doses has not shown any side effects. From the current literature, there is not much data concerning the effects of $C$. proximus.

In the present study, we report the composition, the antimicrobial and antioxidant activity of the Eo and methanolic extract obtained from endemic Egyptian C. proximus Stapf for the first time.

\section{MATERIALS AND METHOD}

\subsection{Plant samples}

For this study fresh plant material was used. The plant was collected during the vegetation period, botanically identified and immediately processed. Specimens were identified at the Botany Department, Faculty of Science, Suez Canal University (Ismailia, Egypt) and voucher specimens were deposited at the Herbarium of the Department of Botany in the cited university.

\subsection{Preparation of the methanol extract}

The powder form of $C$. proximus $(50 \mathrm{~g})$ was extracted with methanol $(200 \mathrm{ml} \times 3$ times $)$ at room temperature. The methanol extract was combined and evaporated by a vacuum rotary evaporator at $45^{\circ} \mathrm{C}$ to the dried powdered form (yield $12.96 \%$, $\mathrm{w} / \mathrm{w}$ ). The resulting extract was then lyophilized and kept in the dark at $+4{ }^{\circ} \mathrm{C}$ until tested.

\subsection{Preparation of essential oil}

Eo was obtained using the Clevenger hydrodistillation method. The plant material (about 300 g), was cut into small pieces, and placed in a flask
(4 I) together with doubly distilled water (1.5 I). The mixture was boiled for $3 \mathrm{~h}$, the collected Eo was dried with anhydrous sodium sulphate and kept at $-18^{\circ} \mathrm{C}$ until use.

\subsection{GC and GC-MS analysis conditions of the essential oil}

GC analysis was performed on a Hewlett Packard 5890 II gas chromatograph equipped with a FID and HP-5ms capillary column (bonded and cross-linked 5\%- phenyl-methylpolysiloxane $30 \mathrm{~m}$. $0.25 \mathrm{~mm}$ i.d., film thickness $0.25 \mathrm{Im}$ ). Injector and detector temperatures were set at 220 and $290^{\circ} \mathrm{C}$, respectively. The oven temperature was held at $50^{\circ} \mathrm{C}$ for $3 \mathrm{~min}$, then programmed to $240^{\circ} \mathrm{C}$ at a rate of $3^{\circ} \mathrm{C} / \mathrm{min}$. Helium was the carrier gas, at a flow rate of $1 \mathrm{~mL} / \mathrm{min}$. Diluted samples $(1 / 100$ in acetone, v/v) of $1.0 \mathrm{IL}$ were injected manually and in the splitless mode. Quantitative data were obtained electronically from FID area percent data. GC-MS analysis of the Eo was performed under the same conditions with GC (column, oven temperature, flow rate of the carrier gas) using a Hewlett Packard 5890 II gas chromatograph equipped with a Hewlett Packard 5972 mass selective detector in the electron impact mode $(70 \mathrm{eV})$. Injector and MS transfer line temperatures were set at 220 and $290^{\circ} \mathrm{C}$, respectively. The components were identified based on the comparison of their relative retention time and mass spectra with those of standards, NBS75K library data of the GC-MS system and literature data (Adams, 2001). Alkanes were used as reference points in the calculation of relative retention indexes $(\mathrm{RRI})$.

\subsection{Antimicrobial Tests}

\section{Microbial strains}

The bacterial and yeast strains used in this work are described in Table 2. These microbial strains were isolated from human beings (other than ATCC strains) and belong to the microbiological laboratory collection of the department of microbiology from Suez Canal University, Egypt. Nutrient agar (for bacterial strains) and Sabouraud dextrose agar media (for yeast strains) were inoculated with this suspension of the respective organism and poured into a sterile petri dish.

\section{Disc-diffusion assay}

The agar diffusion assay was performed according to the modified Kirby-Bauer disc diffusion method (Robert et al., 2003). One $\mathrm{ml}$ of each test organism liquid culture was individually suspended in $3 \mathrm{ml}$ of a $0.9 \% \mathrm{NaCl}$ solution. The Eo and methanol extract were dissolved in $10 \%$ dimethylsulfoxide (DMSO) to a final concentration of $30 \mathrm{mg} / \mathrm{ml}$ as stock solution and sterilized by filtration through $0.45 \mu \mathrm{m}$ Millipore filters. Antimicrobial tests were then carried out using $100 \mu \mathrm{l}$ of suspension containing $10^{8} \mathrm{cfu} / \mathrm{ml}$ of bacteria 
and $10^{6} \mathrm{cfu} / \mathrm{ml}$ of yeast spread on nutrient agar and Sabouraud dextrose agar media, respectively. The discs (6 $\mathrm{mm}$ in diameter) were impregnated with 5 $\mu \mathrm{g}$ of the essential oil and methanol extract, and then placed onto inoculated agar. Negative controls were prepared using the same solvent employed to dissolve the extract. The inoculated plates were incubated at $37^{\circ} \mathrm{C}$ for $24 \mathrm{~h}$ for clinical bacterial strains and $48 \mathrm{~h}$ for yeast isolates. Antimicrobial activity was evaluated by measuring the zone of inhibition against the test organisms.

\section{Micro-well dilution assay of MIC and MBC}

The minimal inhibitory concentration (MIC) values of the Eo and methanol extract were studied using the micro-well dilution method for the bacterial strains which were sensitive to Eo and methanol extract in the disc diffusion assay. In brief, the 96-well plates were prepared by dispensing $95 \mu \mathrm{l}$ of nutrient broth and $5 \mu \mathrm{l}$ of the inocula into each well. The inocula of the bacterial strains were prepared from $12 \mathrm{~h}$ broth cultures and suspensions were adjusted to $0.5 \mathrm{McF}$ arland standard turbidity. One hundred $\mu \mathrm{l}$ aliquot from the stock solutions of the Eo and methanol extract initially prepared at the concentration of $10 \mathrm{mg} / \mathrm{ml}$ were added into the first wells. Then, $100 \mu \mathrm{l}$ from their serial dilutions were transferred into six consecutive wells. The last well containing $195 \mu \mathrm{l}$ of nutrient broth without the compound and $5 \mu \mathrm{l}$ of the inocula on each strip was used as a negative control. The final volume in each well was $200 \mu \mathrm{l}$. The plate was covered with a sterile plate sealer. The contents of each well were mixed on a plate shaker at $300 \mathrm{rpm}$ for $20 \mathrm{~s}$ and then incubated at appropriate temperatures for 24 h. Microbial growth was determined by plating $5 \mu \mathrm{l}$ samples from clear wells on nutrient agar medium. The extract tested in this study was screened twice against each organism. The MIC was defined as the lowest concentration of the compounds to inhibit the growth of microorganisms. MBC (minimum bactericidal concentration) is usually an extension from the MIC, where the organisms quantitatively indicate the minimum concentration when no viable organism appears in the culture.

\section{Cell viability assay for Bacillus cereus and Salmonella choleraesuis}

Each of the tubes containing bacterial suspension (approximately $10^{6} \mathrm{cfu} / \mathrm{mL}$ ) of Bacillus cereus and Salmonella choleraesuis was inoculated with 0.25 , 0.5 and $1 \%$ concentration of C. proximus Eo in 10 $\mathrm{mL} \mathrm{MHB}$, and kept at $37^{\circ} \mathrm{C}$. Samples for viable cell counts were taken at $0,5,10,15,20,40,60$ and 120 min time intervals. The viable plate counts were monitored as followed: $100 \mu \mathrm{l}$ sample of each treatment was diluted and spread on the surface of MHB agar. The colonies were counted after $24 \mathrm{~h}$ of incubation at $37^{\circ} \mathrm{C}$. The controls were inoculated without Eo for each bacterial strain with the same experimental condition as mentioned above.

\subsection{Antioxidant activity}

\section{Determination of total antioxidant capacity}

The assay is based on the reduction of $\mathrm{Mo}(\mathrm{VI})-$ Mo (V) by the extract and subsequent formation of green phosphate/Mo (V) complex at acidic $\mathrm{pH}$ (Archana et al., 2005). The $0.1 \mathrm{~mL}$ extract was combined with $3 \mathrm{~mL}$ of a reagent solution $(0.6 \mathrm{M}$ sulphuric acid, $28 \mathrm{mM}$ sodium phosphate and $4 \mathrm{mM}$ ammonium molybdate). The tubes were incubated at $95^{\circ} \mathrm{C}$ for $90 \mathrm{~min}$. This solution was allowed to cool at room temperature and the absorbance of the solution was measured at $695 \mathrm{~nm}$ against a blank. The antioxidant activity was expressed as the number of equivalents of ascorbic acid.

\section{DPPH assay}

The hydrogen atoms or electron donation ability of the corresponding extracts and some pure compounds was measured from the bleaching of the purple colored methanol solution of DPPH. This spectrophotometric assay uses the stable radical diphenylpicrylhydrazyl (DPPH) as a reagent (Burits and Bucar, 2000; Cuendet et al., 1997). Fifty microliters of various concentrations of the extracts in methanol were added to $5 \mathrm{ml}$ of a $0.004 \%(w / v)$ methanol solution of DPPH. After a $30 \mathrm{~min}$ incubation period at room temperature the absorbance was read against a blank at $517 \mathrm{~nm}$. Inhibition of the free radical DPPH in percent (I \%) was calculated in the following way:

$$
1 \%=\left(A_{\text {blank }}-A_{\text {sample }} / A_{\text {blank }}\right) \times 100
$$

Where $A_{\text {blank }}$ is the absorbance of the control reaction (containing all reagents except the test compound), and $A_{\text {sample }}$ is the absorbance of the test compound. $I_{50}$ values (concentration of sample required to scavenge $50 \%$ of free radicals) were calculated from the regression equation, prepared from the concentration of the essential oil or the extract and the percentage inhibition of free radical formation/percentage inhibition of the DPPH was assayed. Synthetic antioxidant reagents, butylated hydroxyanisole (BHA) and L-ascorbic acid were used as positive controls.

\subsection{Statistical Analysis}

The variations between experiments were estimated by standard deviations and the statistical significance of changes was estimated using the student's t-test. Only the probability $\mathrm{P} \leq 5 \%$ was regarded as indicative of statistical significance.

\section{RESULTS}

\subsection{GC-MS analysis of essential oil}

The hydrodiztillation of dried C. proximus gave a brownish Eo (yields $0.58 \%$, w/w). The identified 
compounds, qualitative and quantitative analytical results by $\mathrm{GC}$ and $\mathrm{GC} / \mathrm{MS}$ are shown in Table 1 , according to their elution order on a ZB-1 capillary column. The GC-MS analysis of the Eo led to the identification of 19 different components, representing $95.47 \%$ of the total oil constituents (Table 1 ). A total of 19 constituents representing $95.47 \%$ of the oil were identified; piperitone $(72.44 \%)$, elemol (9.43\%), $\alpha$-eudesmol (4.34\%), limonene $(2.45 \%)$ and $\beta$-eudesmol $(1.26 \%)$ were the main components comprising $88.92 \%$ of the oil. A portion (4.53\%) of the total composition was not identified. The Eo yield from the whole plants of $C$. proximus prepared by the hydrodiztillation method was $0.58 \%(\mathrm{v} / \mathrm{w})$. GC/MS analysis revealed that the oil contained 19 components in the oil containing piperitone (72.44\%).

\subsection{Antimicrobial activity}

The in vitro antimicrobial potential of $C$. proximus Eo and methanol extract against a panel of microorganisms is shown in Table 2. Eo showed moderate in vitro antimicrobial activity against all tested bacteria, including Gram positive and Gram negative ones with diameter zones of inhibition 3 to $20 \mathrm{~mm}$, along with MIC and MBC values ranging from 0.25 to $1 \mu \mathrm{l} / \mathrm{ml}$. Whereas the methanol extract showed less antimicrobial activity. The diameters of inhibition zones found were in the range of 5 to 20 $\mathrm{mm}$, along with $\mathrm{MIC}$ and $\mathrm{MBC}$ values ranging from 0.5 to $5 \mathrm{mg} / \mathrm{ml}$.

In the comparison of microbial sensitivity to both Eo and methanol extracts, Bacillus cereus and Salmonella choleraesuis seem to be more sensitive than other infectious pathogens such as Enterococcus sp., E. coli 0157:H7 and Proteus vulgaris. The results of antimicrobial activity are shown in Table 2. According to the statistical analysis, the gram-positive $B$. cereus was the most sensitive strain, with MIC values ranging from $0.25 \mu \mathrm{g} / \mathrm{ml}$ to $5 \mu \mathrm{g} / \mathrm{ml}$. No remarkable activity was observed against the the yeast $C$. Albicans, which turned out to be the most resistant strain. Further, the effect on the cell viabilities of $B$. cereus and $S$. choleraesuis demonstrated that exposure of Eo at $0.25,0.5$ and $1 \%$ concentration of $C$. proximus Eo had a potential antibacterial effect on the viabilities of $B$. cereus and $S$. choleraesuis strains. The exposure times of Eo for the complete inhibition of cell viability of $B$. cereus and $S$. choleraesuis were found to be $0.5 \%$ at 10 min and $1 \%$ at $10 \mathrm{~min}$, respectively (Fig. 1a and b).

\subsection{Antioxidant activity}

The total antioxidant activity of the $C$. proximus was expressed as the number of equivalents of ascorbic acid (ASE). The antioxidant capacity was estimated from the regression equation derived from

Table 1

Percentage chemical composition of the essential oil Cymbopogon proximus Stapf

\begin{tabular}{|c|c|c|c|}
\hline Peak No & Compound $^{a}$ & $\mathrm{KI}^{\mathrm{b}}$ & $\operatorname{Area}^{c}(\%)$ \\
\hline 1 & Limonene & 481 & 2.45 \\
\hline 2 & $\alpha$-Pinene & 940 & 0.74 \\
\hline 3 & Piperitone & 1011 & 72.44 \\
\hline 4 & $\delta$-3-Carene & 1012 & 0.77 \\
\hline 5 & $\alpha$-Terpinene & 1019 & 0.25 \\
\hline 6 & p-Cymene & 1025 & 0.68 \\
\hline 7 & 1,8-Cineole & 1033 & 0.27 \\
\hline 8 & (Z)- $\beta$-Ocimene & 1040 & 0.48 \\
\hline 9 & (E)- $\beta$-Ocimene & 1048 & 0.25 \\
\hline 10 & $\gamma$-Terpinene & 1063 & 0.12 \\
\hline 11 & $\alpha$-Terpinolene & 1089 & 0.07 \\
\hline 12 & Linalool & 1098 & 0.07 \\
\hline 13 & Linalyl acetate & 1262 & 0.35 \\
\hline 14 & $\beta$-Bourbobene & 1380 & 0.14 \\
\hline 15 & $\beta$-Elemene & 1388 & 0.82 \\
\hline 16 & Elemol & 1540 & 9.43 \\
\hline 17 & $\gamma$-Eudesmol & 1951 & 0.54 \\
\hline 18 & $\beta$-Eudesmol & 1993 & 1.26 \\
\hline 19 & $\alpha$ - Eudesmol & 2000 & 4.34 \\
\hline \multicolumn{3}{|c|}{ Oil yield (\%) (v/w) } & 0.58 \\
\hline
\end{tabular}

${ }^{a}$ Components were identified through $\mathrm{KI}$ and GC-MS (gas chromatograph coupled with mass spectrometry) and listed according to their elution on HP-5 MS capillary column $(30 \mathrm{~m})$. ${ }^{\mathrm{B}} \mathrm{KI}$ : Kovats indexes on HP-Innowax capillary column in reference to C9-C28 $\mathrm{n}$-alkanes (Adams, 2001). ${ }^{c}$ The 19 constituents identified represent $95.47 \%$ of the total area. 
Table 2

Antimicrobial activity of the essential oil and methanol extract from of Cymbopogon proximus Stapf

\begin{tabular}{|c|c|c|c|c|c|c|c|}
\hline & \multirow[b]{2}{*}{ Origin } & \multicolumn{3}{|c|}{ Essential oil } & \multicolumn{3}{|c|}{ Methanol extract } \\
\hline & & $\mathrm{DD}^{\mathrm{a}}$ & MIC & MBC & DD & MIC & MBC \\
\hline \multicolumn{8}{|l|}{ Gram Positive Bacteria } \\
\hline Bacillus cereus & ATCC 11778 & 22 & 0.25 & 0.5 & 20 & 0.5 & 1 \\
\hline Bacillus megaterium & Human & 9 & 5 & 5 & 5 & 5 & 5 \\
\hline Bacillus subtilis & Human & - & - & - & - & - & - \\
\hline Enterococcus faecium & Human & - & - & - & - & - & - \\
\hline Enterococcus feacalis & Human & - & - & - & - & - & - \\
\hline Micrococcus luteus & Human & - & - & - & - & - & - \\
\hline Serratia marcescens & Human & - & - & - & - & - & - \\
\hline Staphlococcus aureus & Human & 7 & 2 & 3 & - & - & - \\
\hline \multicolumn{8}{|l|}{ Gram Negative Bacteria } \\
\hline Bordetella bronchisepta & ATCC 4617 & 7 & 5 & 5 & 5 & 5 & 5 \\
\hline Escherichia coli & Human & 10 & 3 & 5 & 5 & 4 & 5 \\
\hline Escherichia coli O157:H7 & Human & - & - & - & - & - & - \\
\hline Klebsiella pneumonia & Human & 5 & 5 & 5 & 3 & 5 & 5 \\
\hline Proteus vulgaris & Human & - & - & - & - & - & - \\
\hline Pseudomonas aeruginosa & Human & 7 & 5 & 5 & 3 & 5 & 5 \\
\hline Salmonella choleraesuis & ATCC 19430 & 20 & 0.5 & 1 & 18 & 1 & 1 \\
\hline \multicolumn{8}{|l|}{ Yeast } \\
\hline Candida albicans & ATCC 44831 & - & - & - & - & - & - \\
\hline Candida utilis & Human & - & - & - & - & - & - \\
\hline Saccharomyces cerevisiae & Human & - & - & - & - & - & - \\
\hline
\end{tabular}

MIC (minimum inhibition concentration) and MBC (minimum bactericidal concentration) as mg/ml of essential oil or methanol extract; (-) no antimicrobial activity. Values are the average of three trails. ${ }^{\text {a }}$ Inhibition zone in diameter (mm) around the discs impregnated with essential oil and methanol extract ( $5 \mathrm{mg} / \mathrm{disc})$.

concentration versus optical density of the sample and ascorbic acid. The extraction by methanol showed equivalents $48.66 \pm 3.1 \mu \mathrm{g}$ dried $C$. proximus. The color of the reaction mixture changes from purple to yellow, and its absorbance at wavelength $517 \mathrm{~nm}$ decreases. Table 3 shows the DPPH radical scavenging activities of the essential oil and methanol extract of $C$. proximus. The $I_{50}$ values were compared with the $\mathrm{IC}_{50}$ values of butylated hydroxyanisole (BHA) and ascorbic acid. A lower $I_{50}$ value indicates greater antioxidant activity. The $\mathrm{IC}_{50}$ values of the essential oil and methanol extract were found to be $998.47 \pm 67.65$ and $48.66 \pm 3.1$, respectively. The scavenging effects of $\mathrm{BHA}$ and ascorbic acid were found to be 2.77 and 3.3 times greater than the methanol extract of C. proximus, respectively. The methanol extracts of $C$. proximus showed a highly effective free radical scavenging in the DPPH assay. These extracts exhibited a remarkable antioxidant effect at low concentrations. The essential oil of $C$. proximus was only slightly active.

\section{DISCUSSION}

In this study it was found that the percentage and piperitone $(72.44 \%)$ compositions of Eo of $C$. proximus was similar to the Eo obtained from the C. proximus leaves of Egyptian origin (EI Tahir and Abdel Kader, 2008). The chemical profiles of the Eo from the leaves and buds differ not only in the number of molecules but also in the stereochemical types of molecules extracted. Other components of the oil are known constituents of the plants (El Tahir and Abdel Kader, 2008). The analysis of the oil sample from the Sudanese sample was free of that component (Siddiqui et al., 1980). It is most likely that this difference is the result of a misidentification of the Sudanese sample. This could be attributed to several factors such as climate, soil composition, season, edaphic factors, plant organ, age, and vegetative cycle stage (Angioni et al., 2006).

The antibacterial activity of the oil of $C$. proximus could, in part, be associated with major constituents such as $\alpha$-terpinene, linalool, $\alpha$-pinene and $\gamma$-terpinene. These components have been reported to display antibacterial effects (Alessandra et al., 2005; Djoukeng et al., 2005). Terpenes were active against bacteria (Djoukeng et al., 2005). As described previously by other authors, Eo containing terpenoids are more active against Gram positive bacteria than against Gram negative bacteria (Cosentino et al., 1999). In addition, the components in lower amounts 
Table 3

Scavenging activity of the DPPH radical of the essential oil and methanol extract from Cymbopogon proximus Stapf

\begin{tabular}{|c|c|c|c|}
\hline Samples & Concentration $(\mu \mathrm{g} / \mathrm{mL})$ & Inhibition (\%) & IC50 values $(\mu \mathrm{g} / \mathrm{mL})$ \\
\hline \multirow[t]{3}{*}{ Essential oil } & 500 & 40.63 & \\
\hline & 1000 & 60.94 & $998.47 \pm 67.65$ \\
\hline & 1500 & 63.75 & \\
\hline \multirow[t]{3}{*}{ Methanol extract } & 10 & 39.38 & \\
\hline & 50 & 59.98 & $48.66 \pm 3.1$ \\
\hline & 100 & 89.88 & \\
\hline \multirow[t]{3}{*}{ Butylated hydroxyanisole ${ }^{a}$} & 10 & 28.39 & \\
\hline & 20 & 57.03 & $17.58 \pm 0.63$ \\
\hline & 30 & 85.11 & \\
\hline \multirow[t]{2}{*}{ Ascorbic acid ${ }^{a}$} & 10 & 49.76 & $14.73 \pm 0.55$ \\
\hline & 20 & 67.87 & \\
\hline
\end{tabular}

${ }^{a}$ References control.

may also contribute to the antibacterial activity of the oil, probably involving some type of synergism with other active compounds. The NCCLS method (NCCLS, 2000) was used to determine the antibioticresistance and sensitivity pattern profile of the antibiotic- resistant bacteria.
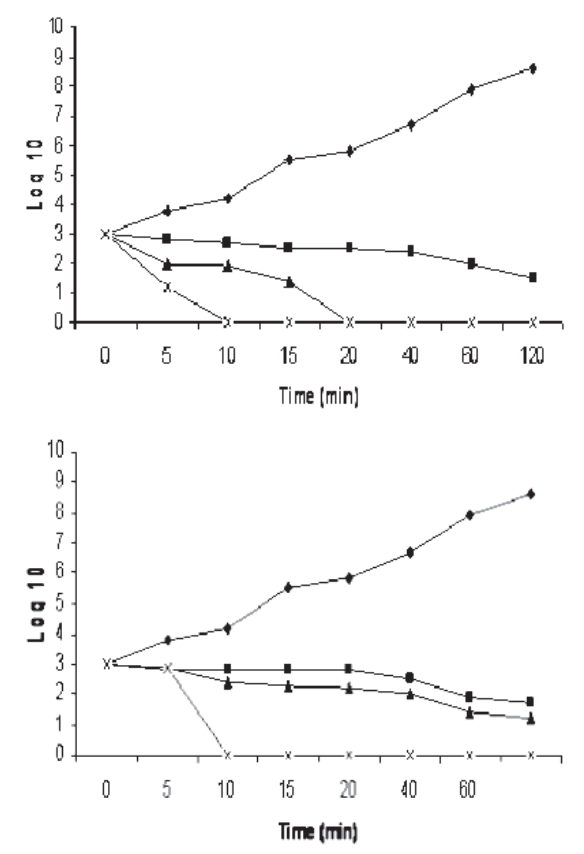

Figure 1

Effect of essential oil from C. proximus as 0 (control, $\downarrow$ ), $0.25(\mathbf{\square}), 0.50(\boldsymbol{\Delta})$, and $1 \%(\mathrm{x})$ on viability of (a) Bacillus cereus and (b) Salmonella choleraesuis. Values are the average of three individual replicates (means $\pm S$.D). Differences between samples were determined by the Student's t-test and were considered to be significant when $p \leq 0.05$.
The DPPH free radical is a stable free radical, which has been widely used as a tool to estimate the free radical-scavenging activity of antioxidants. Antioxidants, upon interaction with $\mathrm{DPPH}$, either transfer electrons or hydrogen atoms to DPPH, thus neutralizing the free radical character (Archana et al., 2005). The key role of phenolic compounds as antimicrobial and scavengers of free radicals is emphasized in several reports (Rauha et al., 2000; Archana et al., 2005). Here we propose, for the first time, the use of essential oil and the methanol extract of $C$. proximus as potential antimicrobial and antioxidant sources. According to Borchers, Keen and Geratiwin (Borchers et al., 2004), food extracts may be more beneficial than isolated constituents, because other compounds present in the extracts can be change the properties of an individual bioactive component.

In this research, we found that the essential oil and methanol extract of $C$. proximus severely inhibited the growth of food spoilage, food-borne pathogens, and multiantibiotic-resistant bacteria. In addition, the Eo and methanol extract also exhibited a strong scavenging effect on DPPH free radicals. Therefore, from the above results, it can be concluded that the essential oil and methanol extract derived from $C$. proximus could be considered potential alternatives for synthetic bactericides and natural antioxidants for use in the food industry along with their possible applications in the pharmaceutical industry for the prevention or treatment of severe skin diseases caused by emerging antibiotic resistant microorganisms and free radicals. The antioxidative and antimicrobial properties of the essential oils and various extracts from many plants are of great interest in both academia and the food industry, since their 
possible use as natural additives emerged from a growing tendency to replace synthetic antioxidants by natural ones. In this respect, studying the endangered species may be of great interest, since their bioactive properties and secrets could be lost forever if left untapped. Owing to its strong antibacterial and excellent protective features exhibited in antioxidant activity tests, the essential oil and extracts from C. proximus could be concluded as a natural source that can be freely used in the food industry as a culinary herb, but, firstly, immediate and necessary measurements should be taken for the protection of this plant species. In conclusion, this study can be considered as the first report on the in vitro antimicrobial and antioxidant properties of the essential oil and methanol extracts prepared from C. proximus. I hope that our results introduce a unique natural source which possesses strong antimicrobial and antioxidant substances.

\section{ACKNOWLEDGEMENTS}

The author would like to thank Dr. Domenico Pangello, Environmental and Food Laboratory, Department of Genomics and Biotechnology, Institute of Molecular Biology, Slovak Academy of Sciences for his support and assistance during this investigation.

\section{REFERENCES}

Adams RP. 2001. Quadrupole mass spectra of compounds listed in order of their retention time on DB-5. Identification of essential oils components by gas chromatography/ quadrupole mass spectroscopy. Allured Publishing Corporation, Carol. Stream, IL, USA, p. 456.

Alessandra LO, Roberta BL, Fernando AC, Marcos NE. 2005. Volatile compounds from pitanga fruit (Eugenia uniflora L.). Food Chem. 99, 1-5.

Angioni A, Barra A, Coroneo V, Dessi S, Cabras P. 2006. Chemical composition, seasonal variability, and antifungal activity of Lavandula stoechas L. ssp. stoechas essential oils from stem/leaves and flowers. $J$. Agric. Food Chem. 54, 4364-4370.

Appendini P, Hotchkiss JH. 2002. Review of antimicrobial food packaging. Innovative Food Science and Emerging Technologies 3, 113-126.

Archana B, Dasgupta N, De B. 2005. In vitro study of antioxidant activity of Syzygium cumini fruit. Food Chem. 90, 727-733.

Borchers AT, Keen CL, Gerstiwin ME. 2004. Mushrooms, tumors, and immunity: an update. Exp. Biol. Med. 229, 393-406.

Boulos L. 1983. Medicinal Plants of North Africa. Reference Publication Inc.: Michigan, 92.

Cosentino S, Tuberoso CIG, Pisano B, Satta MV, Arzedi E, Palmas F. 1999. In vitro antimicrobial activity and chemical composition of Sardinian Thymus essential oils. Lett. Appl. Microbiol. 29, 130-135.
Daferera DJ, Ziogas BN, Polissiou MG. 2003. The effectiveness of plant essential oils on the growth of Botrytis cinerea, Fusarium sp. and Clavibacter michiganensis subsp. Michiganensis. Crop Protection 22, 39-44.

Djoukeng JD, Mansour EA, Tabacchi R, Tapondjou AL, Bouda H, Lontsi D. 2005. Antibacterial triterpenes from Syzygium guineense (Myrtaceae). J. Ethnopharmacol. 101, 283-286.

El-Askary HI, Meselhy MR, Galal AM. 2003. Sesquiterpenes from Cymbopogon proximus. Molecules 8, 670-677.

El Tahir KEH, Abdel Kader MS. 2008. Chemical and Pharmacological Study of Cymbopogon proximus Volatile Oil. Research Journal of Medicinal Plant 2 (2), 53-60.

Hammer KA, Carson CF, Riley TV. 1999. Antimicrobial activity of essential oils and other plant extracts. Journal of Applied Microbiology 86, 985-990.

Leimanna FV, Gonçalvesb OH, Machadoa RAF, Bolzan A. 2009. Antimicrobial activity of microencapsulated lemongrass essential oil and the effect of experimental parameters on microcapsules size and morphology. Materials Science and Engineering 29 (2), 430-436.

NCCLS (National Committee for Clinical Laboratory Standards) 2000. Methods for dilution antimicrobial susceptibility tests for bacteria that grow aerobically. Approved Standard, M7-A5.

Onawunmi GO. 1980. Evaluation of the antifungal activity of lemongrass oil. Pharmaceutical Biology 27, 121-126.

Pereira RS, Sumita TC, Furlan MR, Jorge AOC, Ueno M. 2004. Antibacterial activity of essential oils on microorganisms isolated from urinary tract infection. Rev. Saúde Pública 38, 326-328.

Radwan AS. 1975. An analytical method for proximadiol, the active principle of Cymbopogon proximus. Planta Med. 27, 93.

Rauha JP, Remes S, Heinonen M, Hopia A, Kahkonen M, Kujala T, Pihlaja K, Vuorela H, Vuorela P. 2000. Antimicrobial effects of Finnish plant extracts containing flavonoids and other phenolic compounds. Int. J. Food Microbiol. 56, 3-12.

Robert S, Anders RL, Niels F, Frank E. 2003. Evaluation of different disk diffusion/media for detection of methicillin resistance in Staphylococcus aureus and coagulasenegative staphylococci. APMIS 111, 905-914.

Saikia D, Khanuja SPS, Kahol AP, Gurta AP, Kumar S. 2001. Comparative antifungal activity of essential oils and constituents from three distinct genotypes of Cymbopogon spp. Current Science 80, 1264-1266.

Sayed D. 1980. Traditional medicine in health care. Journal of Ethnopharmacology 2, 19 - 22.

Siddiqui MS, Misra LN, Nigam IM, Abu-Futuh IM. 1980. Chemotaxonomy of Cymbopogon: Gas chromatographic examination of essential oil of Cymbopogon proximus. Parfuemeric und Kosmetik 61, 419-420.

Sokmen A, Jones BM, Erturk M. 1999. The in vitro antibacterial activity of Turkish plants. Journal of Ethnopharmacology 67, 79-86.

Taeckholm V. 1974. Students Flora of Egypt. $2^{\text {nd }}$ Ed.; Cairo University Press: Cairo,759.

Recibido: $15 / 3 / 10$ Aceptado: $19 / 4 / 10$ 